\title{
ASSESSMENT OF THE DYNAMICS OF COASTAL ISLAND IN BANGLADESH USING GEOSPATIAL TECHNIQUES: DOMAR CHAR
}

\author{
KHANDAKER TANVIR HOSSAIN, MD. SALAUDDIN ${ }^{1}$ \\ ISTIAQE AHMED TANIM \\ Department of Geography and Environment, \\ Jagannath University, Dhaka, Bangladesh
}

\begin{abstract}
Erosion and accretion rate are found very high in the estuary of an active delta which can be observed by satellite imageries. According to the multispectral satellite imageries it is found that accretion of Domar Char (a little island belongs to Meghna estuary) was more than 1192 hectares in last 25 years. The study was conducted in five years interval from 1990 to 2015 using spatial analyst extension of ArcGIS. It is revealed that accretion rate is about 208 hectares/year and erosion is about 160 hectares/year, which indicates the dynamic nature of the island. According to Landsat imageries about 2500 hectares of land rose in five years (1990 to 1995) and again lost 2300 hectares of land in next five years (1995 to 2000). Though the total area of intertidal zone has decreased, the area of barren land, vegetation and sand dune has increased over the time.
\end{abstract}

Key words: Shifting, Dynamic, Estuary, Coastline, Intertidal zone, Remote sensing

\section{Introduction}

Shoreline or coastline indicates a dynamic area that changes through short and long term process. Shoreline changes due to sediment shifting are known as morpho-dynamics (Schwartz 2005). Coastal zones are the most complex systems in the world with a large number of both living and non-living organisms (Aedla and Reddy 2015). Climate change and sea-level rising are the current issue in all over the world, especially in Bangladesh which is the worst affected and is facing early impacts of climate change (Sikder 2010). The physiography of coastal area of Bangladesh is more diverse and dynamic than is generally recognized. Failure to recognize this could lead to serious misconceptions about the potential impacts of a rising sea-level on Bangladesh due to global warming (Brammer 2014). Tidal bores are devastating in Chittagong, Cox's Bazar, Barisal, Noakhali, Patuakhali, Barguna and Khulna (Joseph 2006). The recent air temperature is increasing twice faster than the twentieth centuries (IPCC 2001) and average sea level has risen by $3.2 \mathrm{~mm} /$ year (IPCC 2013). Bangladesh is at extreme risk of floods, tropical cyclones, sea level rise and drought, all of which could bound millions of people to migrate (IPCC 2014). A report by UN scientists has projected that rising sea

${ }^{1}$ Corresponding author: E-mail: tanvir.gis@gmail.com 
levels will inundate $17 \%$ of Bangladesh by 2050, making about 30 million people homeless (Dummett 2008). During years of severe flooding in 1987, 1988 and 1998 the country was transformed by intermittent inland seas that occupied as much as $60 \%$ of its land surface (Werle et. al 2000). If the sea-level rises by $45 \mathrm{~cm}$, it may dislocate about 35 million people from 20 coastal districts of Bangladesh by 2050. In an extreme-case scenario, Bangladesh could lose almost 25 percent of its 1989 land area by around 2100 (Alam and Uddin 2013). According to the vulnerability index (Islam et al. 2015), about $57 \mathrm{~km}$ of the entire coast is under very high-risk and another more than $75 \mathrm{~km}$ is under high risk, about $67 \mathrm{~km}$ shoreline is at moderate risk and $63 \mathrm{~km}$ shoreline is at low risk. The most vulnerable coastal regions are found mainly along the western coast of CharFasson and northern and southwestern coast of BholaSadar of Bhola Island (Islam et al. 2015). Islands in the Meghna estuary were especially dynamic; Hatiya Island accreted along some of its shoreline by $50 \mathrm{~km}$ between 1989 and 2009, but has lost $65 \mathrm{~km}^{2}$ through erosion elsewhere, resulting in the island is moving southward (Sarwar and Woodroffe 2013). The areal extent of Urir Char Island gets larger during the monsoon compared to the post monsoon and winter which is expanding at a very high rate of about $3.4 \mathrm{~km}^{2}$ per year (Taguchi et al 2013). The Sandwip Island has gained $25 \mathrm{~km}^{2}$ and lost about $64 \mathrm{~km}^{2}$ through 1980-2014-time period and the net shoreline has shifted by $3.1 \mathrm{~km}$ in this time period (Emranet. al 2016). The coastal zone has countless importance in human life because different studies have revealed that the bulk of humanity is concerted along or near the coasts on just $10 \%$ of the earth's land surface. As of 1998, over half of the population lives and works in a coastal strip with width of just $200 \mathrm{~km}$. Being a low laying deltaic country, the morphology of Bangladesh coastal zone is quite unstable and is changing with the time due to erosion and accretion. Natural threats, such as erosion, water logging and increase in water and soil salinity, risks from climate change like sea-level rise, and cyclone have adversely affected the morphology of coastal zone and reduced the pace of social, economic and infrastructure developments in this region (Shibly and Takewaka 2012). The impacts of this rise are wide-ranging encompassing coastal biological, physical and socio-economic realms such as loss of coastal wetlands, coastal flooding, coastal erosion, salinization of water resources, destroy of usual coastline shield, alteration and loss of coastal biodiversity, decline in fishing stocks, decrease in coastal land area and the migration of human population from the coastline are just some of these example (Blankespoor et al. 2014). Coastal wetlands are also highly exposed to sea level rise (SLR) because of their low elevation and their dependence on the active coastal physico-chemical regime for their unique habitats and species diversity (Nicholls 2004). Change detection can be defined as the process of identifying differences in the state of an object or spectacle by observing it at different times. This process is usually practiced to earth surface changes at two or more times period (Singh 1989). Timely and accurate change detection of earth's surface geographies provides the foundation for better understanding of relationships and interactions between human and natural phenomena towards better management and use 
of resources. The accurate shoreline change extraction and change detection analysis is an important task that has applications in different fields such as development of setback planning, hazard zoning, erosion-accretion studies, regional sediment budgets, adopting different conservation measures e.g. protection of human life, protection of biodiversity, poverty, natural environment and conceptual or predictive modeling of coastal morphodynamics (Aedla and Reddy 2015). Thus, coastal change detection is critical in coastal zone application and is important for the future coastal dynamic studies (Mausel et. al 2004). Therefore, coastal morpho-dynamic studies have greater economic value to the socio-economic development of non-land locked nations (Adegoke et. al 2010). In recent years, satellite remote sensing data is widely used (Lipakis et. al 2008) for different change detection studies and change mapping because of its low cost and reliable information source with high frequency and repeatable observations (Emran et. al 2016). GIS technology has been used by many researchers in measuring, quantifying, calculating and monitoring shoreline rate-of-change statistics from multiple historic shoreline positions and sources (Oyedotun 2014). The repetitive acquisition and synoptic capabilities of remote sensing systems exploited to provide timely spatial data for coastal geographical information systems (GIS) which enables detection and monitoring the shifting of coastline (White and Asmar 1999). As no study on the changes of this coastal island in temporal scale is available, in the present investigation an attempt was taken to measure and compare the erosion and accretion from the year 1990 to 2015 to identify the intertidal zone and their shifting andto analyze the trend of shoreline shifting.

\section{Materials and Methods}

Study area:Domar Char (the wave island) one of two detached limbs of Hatiya Island has stepped into secondary succession, and offer gigantic salt marshes encircled by mudflats and centered by planted mangroves. It is a small island and is extending from $22^{\circ} 1$ ' $30^{\prime \prime} \mathrm{N}$ to $22^{\circ} 5^{\prime} 0$ ” $\mathrm{N}$ latitudes and $91^{\circ} 2^{\prime} 30^{\prime \prime} \mathrm{E}$ to $91^{\circ} 6{ }^{\prime} 30^{\prime} \mathrm{E}$ longitudes where few peoples lives only for fishing and rearing. It is located at south-east part of Hatiya Island and in the eastern portion of Nijhum Dwip (Fig. 1). Recently the forest department started mangrove afforestation along the coast of Domar Char where plantation is possible (Chowdhury 2006). Fig. 1 shows the location of study area.

\section{Materials}

Optical images are simple to interpret and easily obtainable; such images are TM (Thematic Mapper), ETM+ (Enhanced Thematic Mapper) and OLI-TIRS (Operational Land Imager \& Thermal Infrared Sensor) imagery (Niya et. al 2013). In this present study, mainly Landsat 5 TM and Landsat 8 OLI-TIRS sensor images were used. From 1990 to 2015 in five years' interval images were analyzed to fullfil the objectives. The images were downloaded from Global Visualization (Glovis) of United States Geological Survey (USGS). ArcGIS 10.3.1 and Erdas Imagine 2014 were used to analyze the images and MS Excel also used for making Chart and diagram. 


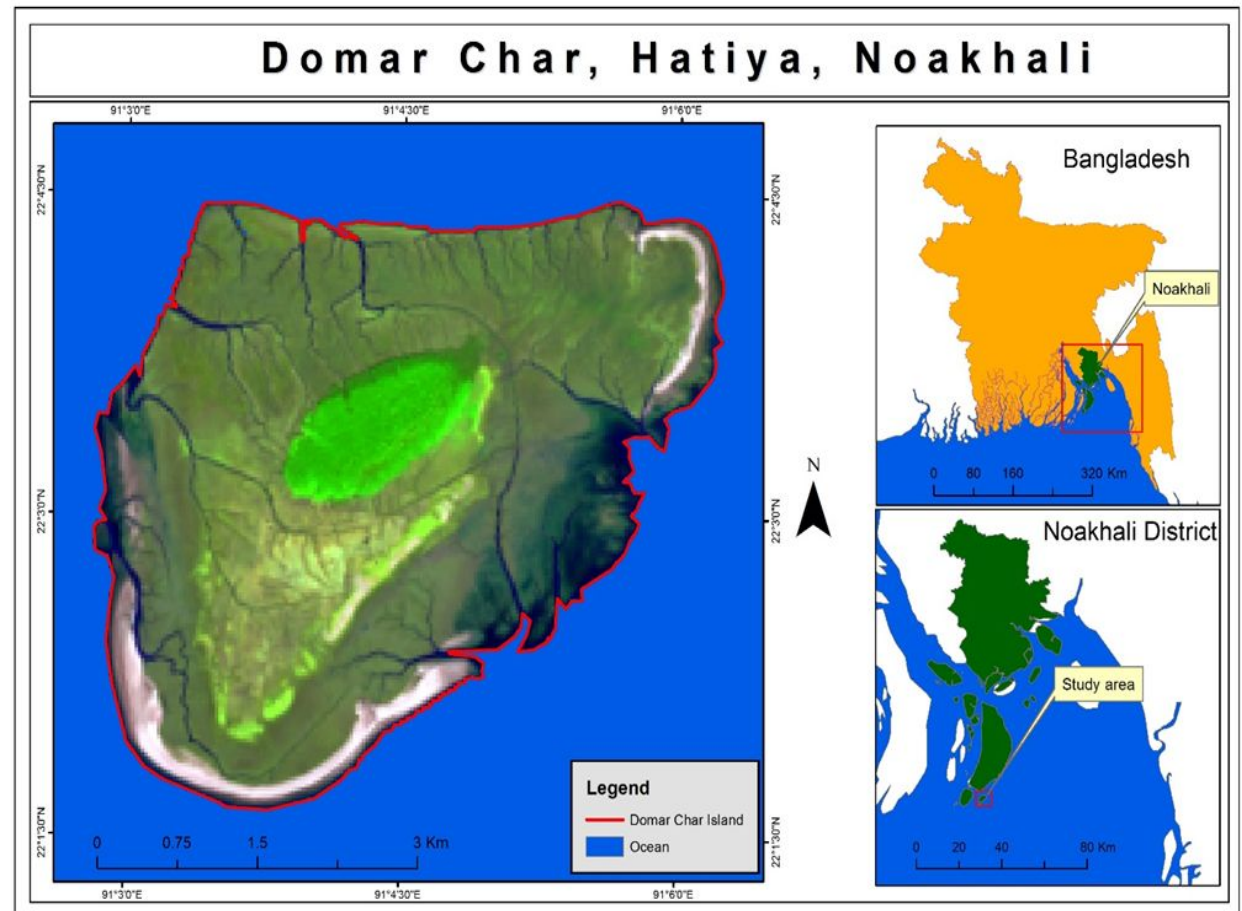

Fig. 1. Study area map.

\section{Methods}

Analysis of coastline changes are generally carried out using survey maps (Kadib 1969), historical coastline mapping, and comparison of beach profiles over a long period of time (Inman and Jenkins 1985). Some other more recent methods including simulation of coastline changes using numerical models; combination of coastline survey using Global Positioning System (GPS) receivers, long-shore sediment transport using numerical modeling packages such as MIKE21 and LITPACK (Pandian et. al 2004) and airborne Light Detection and Ranging. Monitoring shoreline change needs a long-term observation based on the temporal change modelling using remote sensing (RS) and geographic information system (GIS) (Bouchahma and Yan 2012). The use of satellite remote sensing techniques and geographic information systems (GIS) for the identification, mapping and analyses of coastline changes have gained prominence in recent years as high resolution satellite data have become more readily accessible (Adegoke et al. 2010). Data from remote sensors allow users for analyzing of a region with sufficient accuracy in an efficient, rapid and low-cost way (Berlanga-Robles and Ruiz-Luna 2002). In these instances remote sensing is the most beneficial method for different change detection studies. Since the reflection of water in NIR and MIR bands 
are almost zero and most of vegetation has a higher reflection against water, coastline can be extracted using one NIR/MIR band (Ahmadi et. al 2014). The most used water indices are normalized difference water index (NDWI) (McFeeters 1996) and modified normalized difference water index (MNDWI) (Xu 2006). The change detection was assessed by processing of multi-temporal images (1990-2015), by image differencing, post-classification image overlaying, image visual interpretation and onscreen digitizing (Ahmadi et. al 2014). Ground truthing has been conducted using a hand-held GPS (spatial accuracy $+/-5 \mathrm{~m}$ ) through the filed visit to verify the satellite images (Emran et. al 2016). Kappa co-efficient which is an error matrix (Foody 2002) as accuracy assessment was calculated to verify the consistency of the classified images. Overall accuracy is found as $87 \%$ and Kappa co-efficient is found as $81 \%$ indicating high accuracy (Emran et al. 2016).

\section{Results and Discussion}

Erosion-Accretion: Erosion and accretion are common in coastal area since it is dynamic in nature. Domar Char is very dynamic as the large volume of sediment from three great river systems Ganges-Brahmaputra-Meghna (GBM) deposited here. Erosion and accretion rate is very high along the coast of Domar Char. From 1990 to 1995 , accretion occurred significantly of about 2582 hectares and erosion only about 0.34 hectares, whereas unchanged area remains about 979 hectares. From 1995 to 2000, the

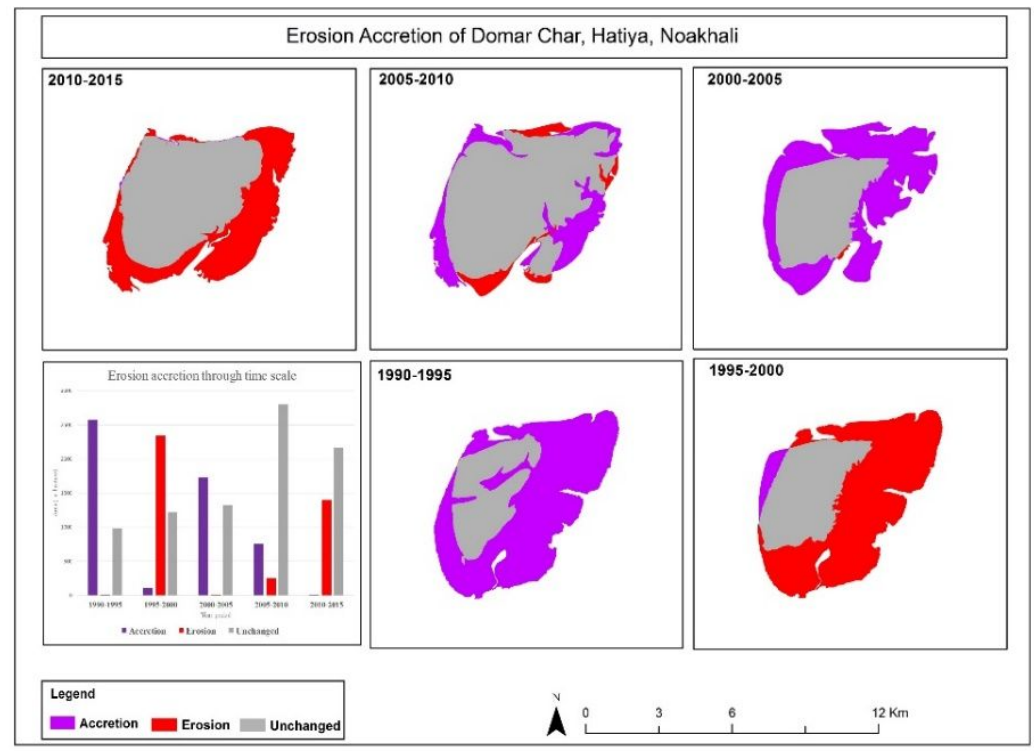

Fig. 2. Erosion-Accretion map of Domar Char Island.

accretion rate was very slow while 113 hectares of land upraised and about 2344 hectares of land was found to be unchanged, as it is a dynamic place erosion and accretion 
rate/trend drastically varies from time to time. In next five years (2000-2005) again the accretion rate was very high (app. 1734 hectares) and stable/unchanged land was about 1321 hectares whereas erosion was insignificant (app. 8 hectares). Unchanged area was doubled in 2005-2010 period, whereas accretion was 758 hectares and erosion was only about 249 hectares. In last five years (2010-2015) the volume of newly deposited land was insignificant and unchanged land decreased while erosion increased about 1398 hectares (Fig. 2). Erosion rate was very high in both second and fifth time period and accretion rate was very high in both first and fifth time periods. Erosion and accretion rate was similar in fourth time period.

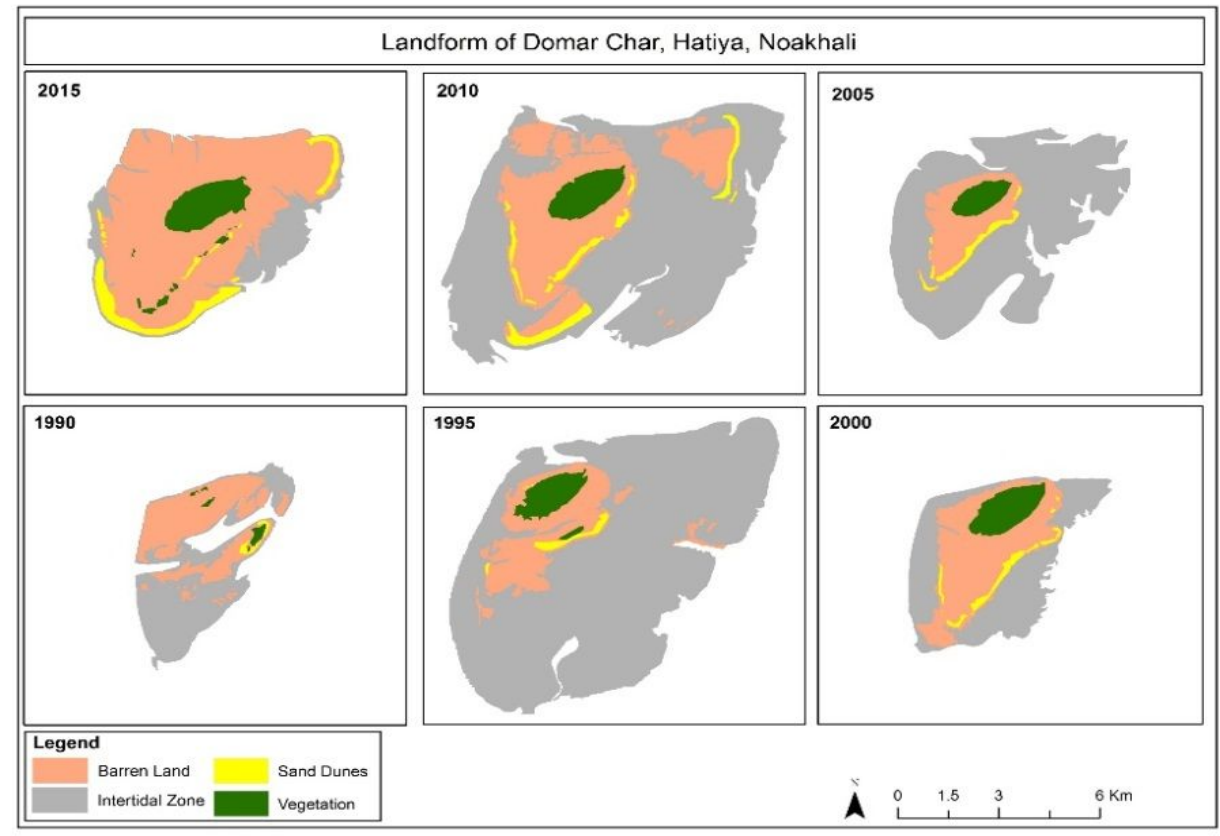

Fig. 3. Landform change map of Domar Char Island.

Intertidal zone: The area between the land and sea that is covered by water at high tide and uncovered at low tide is called intertidal zone or mud flat. Intertidal zone is a very important zone for the coast development. According to the satellite imageries, there was an extreme shifting observed in intertidal zone. In 1990, a very little amount of land was found in the intertidal zone that increased to 3000 hectares in 1995 (Figs. 4 and 5). All other zones (except intertidal) increased in 2000. The intertidal zone increased in 2005 and remain unchanged till 2010 and other zones increased a lot during this time period. The intertidal zone reduced in 2015 but other zones increased (Figs. 4 and 5). From Figs 4 and 5 it is apparent that the amount of high land (vegetation, barren land and sand dunes) over the intertidal zone has increased in the last 25 years. 


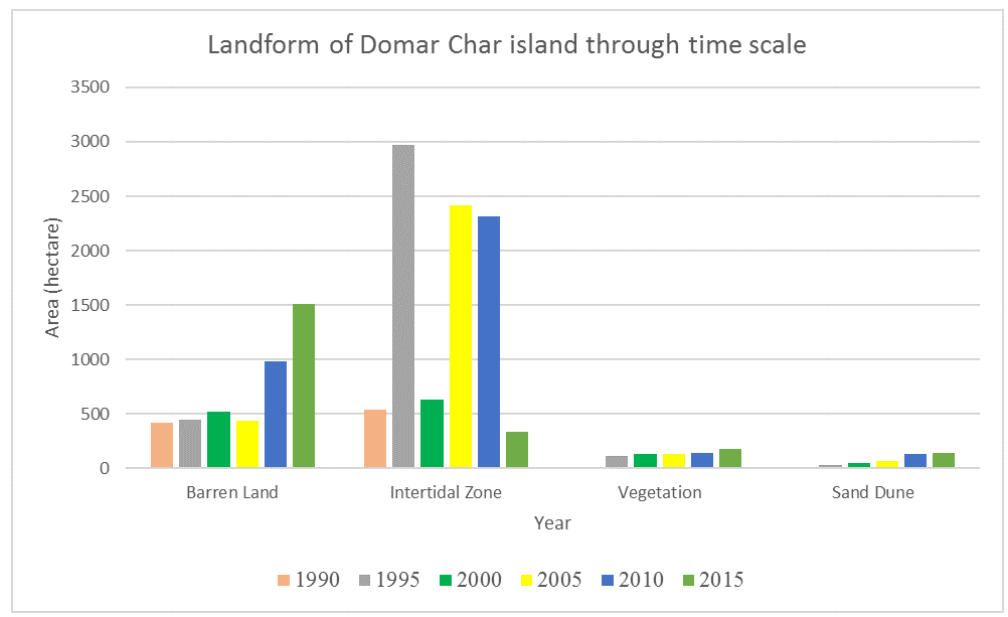

Fig. 4. Landform change graph of Domar Char Island.

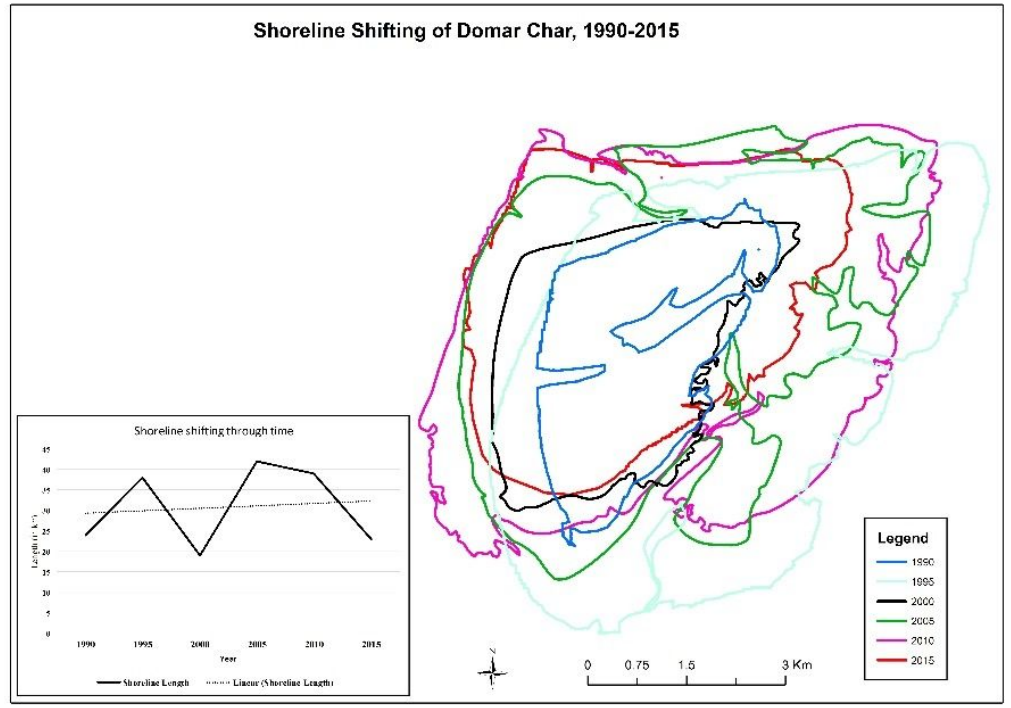

Fig. 5. Shoreline shifting of Domar Char Island.

Shoreline shifting: Shoreline shifting is common in coastal area. The shoreline in the study area has never been constant and is experiencing a dynamic pattern. Both the spatial and temporal variations in the deposition and accretion were observed in the study area. The temporal intervals (being 1990 to 1995,1995 to 2000, 2000 to 2005, 2005 to 2010 and 2010 to 2015 ) were used in the study for assessing the changes. The changing pattern is not uniform. However, the erosion and accretion patterns clearly showed a 
continuous geomorphic sculpturing over the coastal tract in each temporal interval. Net shoreline has just shifted only $-1 \mathrm{~km}$ from 1990 to 2015 which indicates that the island is eroded as well as accreted over the time. In 1995 the shoreline extended to the northern to eastern part whereas in 2000 the shoreline eroded and shifted to the western part. In 2005 Shorelines approached in all parts of the island. In 2010 and 2015 the shoreline shifted only in the western portion of the island. Fig. 5 shows shoreline shifting of Domar Char.

In the context of the sea level rise or tidal bores a proper management plan must be taken to save the coastal areas of Bangladesh from submerging. Despite the dynamic (erosion and accretion) nature of coast, the total land mass of this island has increased in last 25 years. Though the island is expanding over time, the shoreline length has reduced. The Domar char is located at the estuary of Meghna river which is one of the biggest river of Bangladesh. Regular monitoring is required for change detection analysis in coastal morphology.

\section{References}

Adegoke, J. O., M. Fageja, G. James, G. Agbaje and T. E. Ologunorisa. 2010. An Assessment of Recent Changes in the Niger Delta Coastline Using Satellite Imagery. Journal of Sustainable Developmen. 3(4): 277-296.

Aedla, R., G. S. Dwarakish and D. V. Reddy. 2015. Automatic shoreline detection and change detection analysis of netravati-gurpurrivermouth using histogram equalization and adaptive thresholding techniques. Aquatic Procedia, 4: 563-570.

Ahmadi, M., M. Ramesht and K.Derafshi. 2014. Detection of shoreline changes using remote sensing and GIS techniques, case study: Coast port city Dayer, Persian Gulf. Geography and Environmental Planning Journal. 55(3): 15-18.

Alam, M. S. and K. Uddin. 2013. A Study of Morphological Changes in the Coastal Areas and Offshore Islands of Bangladesh Using Remote Sensing. American Journal of Geographic Information System. 2(1): 15-18.

Berlanga-Robles, C. and A. Ruiz-Luna. 2002. Land Use Mapping and Change Detection in the Coastal Zone of Northwest Mexico Using Remote Sensing Techniques. Journal of Coastal Research. 18(3): 514-522.

Blankespoor, B., S. Dasgupta and B. Laplante. 2014. Sea-level rise and coastal wetlands. Ambio, 43(8): 996-1005.doi:10.1007/s13280-014.

Bouchahma, M. and W. Yan, 2012. Automatic measurement of shoreline change on Djerba Island of Tunisia. Computer and Information Science. 5(5): 17.

Brammer, H. 2014. Bangladesh's dynamic coastal regions and sea-level rise. Climate Risk Management. 1: 51-62.

Chowdhury, S. U. 2016. Memoirs of the wave island. Retrieved from The Daily Star: http://www.thedailystar.net.

Dummett, M. 2008. Bangladesh landmass 'is growing'. Dhaka: BBC. Retrieved August 12, 2016. from http://news.bbc.co.uk/2/hi/south_asia/7532949.stm.

Emran, A., M. A. Rob, M. H. Kabir and M. N. Islam. 2016. Modelling spatio-temporal shoreline and areal dynamics of coastal island using geospatial technique. Modelling Earth System Environment. 2(4): 1-11. 
Foody, G. M. 2002. Status of land cover classification accuracy assessment. Remote Sensing of Environment. 80(1): 185-201.

IPCC. 2001. Climate Change 2001: impacts, adaptation and vulnerability. Contribution of Working Group II to the Third Assessment Report.

IPCC. 2013. Climate change 2013: The physical science basis. Summary for Policymakers. Working Group Contribution to the Fifth Assessment Report of the IPCC. IPCC. Retrieved from http://www.ipcc.ch/.

IPCC. 2014. The IPCC Fifth Assessment Report: What's in it for South Asia. Retrieved August 12, 2016. from http://cdkn.org/wp-content/uploads/2014/04/CDKN-IPCC-Whats-in-it-forSouth-Asia-AR5.pdf.

Inman, D. L. and S. A. Jenkins. 1985. The Nile littoral cell and man's impact on the coastal zone of the southeastern Mediterranean. In Coastal Engineering. 1984: 1600-1617.

Islam, M. A., M. S. Hossain and S. Murshed. 2015. Assessment of Coastal Vulnerability Due to Sea Level Change at Bhola Island, Bangladesh: Using Geospatial Techniques. Journal of Indian Society of Remote Sensing. 43(3): 625-637. doi:10.1007/s12524-014-0426-0.

Joseph, P. 2006. Tidal bores, catastrophic flooding in Bangladesh, and the potential usefulness of causeways. Macro Center Working papers. 10.

Kadib, A. 1969. Sand movement along a portion of the northern coast of United Arab Republic . 22nd International Navigation Congress: 273-287.

Lipakis, M., N. Chrysoulakis and Y. Kamarianakis. 2008. Shoreline extraction using satellite imagery. Beach Erosion Monitoring: 81-95.

Mausel, P., Lu, D., E. Brondi'zio and E. Moran. 2004. Change detection techniques. International Journal of Remote Sensing. 25(12): 2365-2407.

McFeeters, S. K. 1996. The use of the Normalized Difference Water Index (NDWI) in the delineation of open water features. International journal of remote sensing. 17(7): 14251432 .

Nicholls, R. 2004. Coastal flooding and wetland loss in the 21st century: changes under SRES climate and socio-economic scenarios. Global Environmental Change: 14: 69-86.

Niya, A. K., A. A. Alesheikh, M. Soltanpor and M. M. Kheirkhahzarkesh. 2013. Shoreline Change Mapping Using Remote Sensing and GIS. International Journal of Remote Sensing Applications. 3(3): 102-107.

Oyedotun, T. D. 2014. Shoreline Geometry: DSAS as a Tool for Historical Trend Analysis. British Society for Geomorphology. 3(2.2): 1-12.

Pandian, P. K., S. Ramesh, M. V. R. Murthy, S. Ramachandran and S. Thayumanavan. 2004. Shoreline changes and near shore processes along Ennore coast, east coast of South India. Journal of Coastal Research. 828-845.

Sarwar, M. M. and C. Woodroffe. 2013. Rates of shoreline change along the coast of Bangladesh. Journal of Coastal Conservation. 17: 515-526.

Schwartz, M. (Ed.). 2006. Encyclopedia of coastal science. Springer Science \& Business Media.

Shibly, A. M. and S. Takewaka. 2012. Morphological Changes along Bangladesh Coast Derived from Satellite Images. Proceedings of Coastal Engineering. JSCE. 3: 41-45.

Sidker, T. 2010. September. The impacts of climate change on the coastal belt of Bangladesh: An investigation of risks \& adaptations on agricultural sector. In Proceedings of international conference on environmental aspects of Bangladesh (ICEAB10).

Singh, A. 1989. Digital change detection techniques using remotely sensed data. International Journal of Remote Sensing. 10: 989-1003. 
Taguchi, Y., M. A. Hussain, Y. Tajima, M. A. Hossain, S., Rana, A. K. M. S. Islam and M. A. Habib. 2013. Detecting Recent Coastline Changes Around the Urir Char Island at the Eastern Part of Meghna Estuary Using PALSAR Images. In: Proceedings of the 4th International Conference on Water and Flood Management.

Werle, D., T. Martin and K. Hasan. 2000. Flood and Coastal Zone Monitoring in Bangladesh with Radarsat ScanSAR: Technical Experience and Institutional Challenges. Johns Hopkins Apl Technical Digest. 21(1): 148-154.

White, K. and H. M. Asmar. 1999. Monitoring changing position of coastlines using thematic mapper imagery, an example from the Nile Delta. Geomorphology. 29: 93-105.

$\mathrm{Xu}, \mathrm{H} .2006$. Modification of normalized difference water index (NDWI) to enhance open water features in remotely sensed imagery. Int J Remote Sens. 27: 3025-3033. 